\section{Frequency of Zygotic Seedlings from Five Polyembryonic Mango Rootstocks}

\author{
Raymond J. Schnell and Robert J. Knight, Jr. \\ Agricultural Research Service, U.S. Department of Agriculture, National \\ Clonal Germplasm Repository, Miami, FL 33158
}

Additional index words. polyembryony, isozymes, Mangifera indica

\begin{abstract}
Five isozyme systems were used to detect zygotic seedlings from five polyembryonic cultivars of mango (Manifera indica $\mathbf{L}$.). Significant differences were found between cultivars $\left(x^{2}=35.53, P<0.001\right)$ for the percentage of zygotic and nucellar seedlings detected. The range of variation in the percentage of off-types was from $0 \%$ in $13-1$ to $64 \%$ in Golek. The percentage in Sabre was $4 \%$, and $24 \%$ and $36 \%$ in Tupentine and Madoe, respectively. Three of eight rootstock mother trees of Turpentine were determined to be off-types.
\end{abstract}

Polyembryony is a common trait in mango cultivars derived from southeastern Asian ancestry (Singh, 1960). Polyembryonic cultivars are popagated from seed and generally come true to type (Knight, 1970). Mango rootstocks are commercially propagated from open-pollinated seed of polyembryonic cultivars. Progeny arising from the open-pollinated seed usually produce uniform populations of nucellar seedlings.

Most polyembryonic mango cultivars occasionally produce morphologically off-type plants that presumably are zygotic in origin. These zygotic seedlings are undesirable as rootstocks because of their unknown effect on the scion. The incidence of these off-types varies among cultivars and may be $\geq 15 \%$, as observed, for example, with commercial rootstock 13-1 in Israel (S. Gazit, personal communication).

Isozymes have been used as biochemical markers to distinguish zygotic from nucellar seedlings in citrus (Moore and Castle, 1988). Isozymes are codominantly inherited, free from environmental effects, the analysis is nondestructive, and the assay is simple, which are all advantages over other methods.

Gazit and Knight (1989) used one enzyme system, glucosed-phosphate isomerase (GPI), and gas chromatography to detect zygotic plants among open-pollinated seedling populations from polyembryonic mango cultivars. Gas chromatograms were too cumbersome for analysis of large plant populations; the isozyme system proved to be simple, repeatable, and cost-effective.

Several enzyme systems have been used to develop a systematic characterization of a diverse array of mango cultivars. Degani et al. (1990) found polymorphisms for six enzyme systems. Genetic inferences were made from gel isozyme patterns with a total of six loci and 17 allelomorphs identified.

The use of a single enzyme system would result in off-type plants being missed if the zygotic plant had the same alleles as the maternal parent. The use of other enzyme systems in addition to GPI should enhance the ability to detect zygotics among seedling rootstock populations of polyembryonic cultivars. Our objective was to determine the frequency of zygotic plants among open-pollinated seedling populations of five polyembryonic mango rootstock populations using five enzyme systems. Golek RSP 13.
During the 1989 mango fruiting season (June-August), 25 seeds were collected from a single tree of each of the following rootstock cultivars: 13-1, Madoe, Sabre, and Golek. Turpentine rootstock seeds were collected from eight separate trees and bulked. Seeds were germinated in flats and transferred to individual pots after seedling emergence. The rootstocks studied are part of a field trial where rootstock effects on commercial production are being investigated; therefore, we were not interested in the total number of nucellar vs. zygotic seedlings produced from each seed. Standard nursery practice was followed, which involved removing all but the most vigorous seedling that germinated from a single seed. Zygotic embryos that give rise to the most vigorous seedlings from a single seed are ultimately used as rootstocks in commercial groves. It is important to know if a rootstock seedling is zygotic or nucellar in origin because of the possible effects on fruit yield and tree vigor.

Five isozyme systems (Degani et al., 1990)
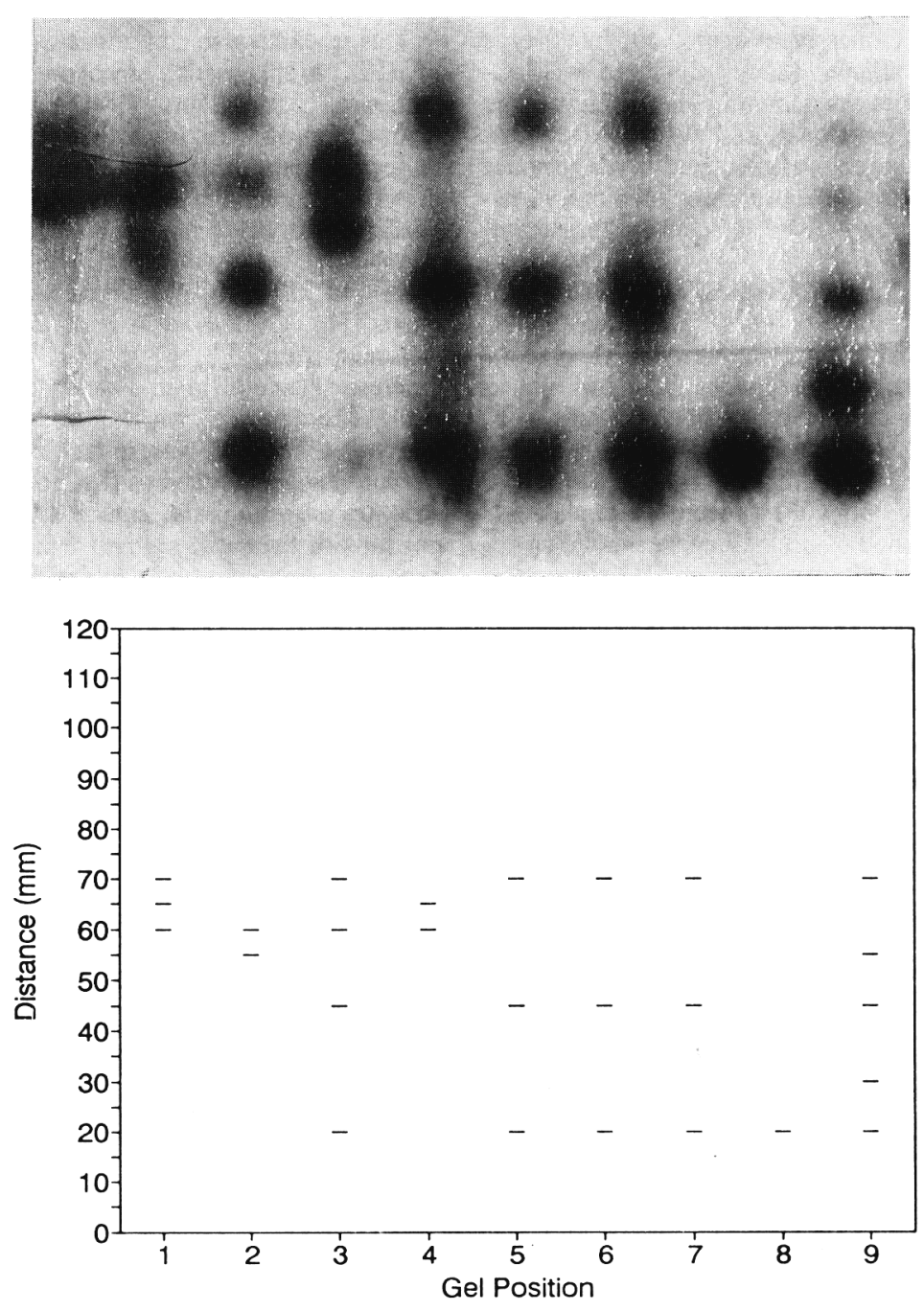

Fig. 1. Isozyme banding patterns (photograph and corresponding diagram) for GPI phenotypes observed among rootstock cultivars and seedlings. Gel position: 1) Madoe, 2) Madoe RSP 1, 3) Madoe RSP 11, 4) Madoe RSP 18, 5) 13-1, 6) Turpentine, 7) Turpentine RSP 2, 8) Turpine RSP 9, 9) 
Table 1. Maternal parent, number of seedlings, percent off-types, and isozyme phenotypes of parents and off-type seedlings for five polyembryonic cultivars.

\begin{tabular}{|c|c|c|c|c|c|c|c|c|}
\hline \multirow{2}{*}{$\begin{array}{l}\text { Maternal } \\
\text { parent/seedling }\end{array}$} & \multirow{2}{*}{$\begin{array}{c}\text { No. } \\
\text { seedlings }\end{array}$} & \multirow{2}{*}{$\begin{array}{c}\text { Percent } \\
\text { off-types }^{y}\end{array}$} & \multicolumn{6}{|c|}{ Isozyme phenotypes ${ }^{x}$} \\
\hline & & & GPI-2 & IDH & LAP & PGM-1 & TPI & Source \\
\hline $13-1$ & 25 & 0 & $\mathrm{AC}$ & $\mathrm{AC}$ & $\mathrm{AA}$ & $\mathrm{AC}$ & $\mathrm{AB}$ & \\
\hline Sabre & 25 & 4 & $\mathrm{AA}$. & $\mathrm{CC}$ & $\mathrm{AA}$ & $\mathrm{AB}$ & AA & \\
\hline Sabre RSP 24 & & & & & & $\mathrm{AC}$ & & e \\
\hline Turpentine & 25 & 24 & $\mathrm{AC}$ & $\mathrm{AC}$ & $\mathrm{AA}$ & $\mathrm{AC}$ & $\mathrm{AB}$ & \\
\hline Turpentine RSP 1 & & & AA & AA & $\mathrm{AB}$ & & BB & $\mathrm{e}$ \\
\hline Turpentine RSP 7 & & & AA & & & & AA & d \\
\hline Turpentine RSP 8 & & & AA & & & & & d \\
\hline Turpentine RSP 9 & & & $\mathrm{CC}$ & $\mathrm{CC}$ & & & BB & d \\
\hline Turpentine RSP 11 & & & AA & $\mathbf{A B}$ & & & & $\mathrm{e}$ \\
\hline Turpentine RSP 10 & & & AA & $\mathrm{AB}$ & & & AA & $\mathrm{e}$ \\
\hline Madoe & 25 & 36 & AB & $\mathrm{CC}$ & $\mathrm{AA}$ & $\mathrm{CC}$ & BB & \\
\hline Madoe RSP 1 & & & a & & & & $\mathrm{AB}$ & $\mathrm{e}$ \\
\hline Madoe RSP 2 & & & & & & & $\mathrm{AB}$ & e \\
\hline Madoe RSP 3 & & & & & & & $\mathrm{AB}$ & $\mathrm{e}$ \\
\hline Madoe RSP 4 & & & & & & & $\mathrm{AB}$ & e \\
\hline Madoe RSP 5 & & & & & & & $\mathrm{AB}$ & $\mathrm{e}$ \\
\hline Madoe RSP 10 & & & $\mathrm{AC}$ & AC & & & $\mathrm{AB}$ & e \\
\hline Madoe RSP 11 & & & b & $\mathrm{AC}$ & & & $\mathbf{A B}$ & e \\
\hline Madoe RSP 18 & & & a & $\mathrm{AC}$ & & & & $\mathrm{e}$ \\
\hline Madoe RSP 25 & & & AA & AC & & & & e \\
\hline Golek & 25 & 64 & $\mathrm{AB}$ & $\mathrm{AC}$ & AA & BB & AA & \\
\hline Golek RSP 1 & & & $\mathrm{AB}$ & & & & & d \\
\hline Golek RSP 2 & & & $\mathrm{AC}$ & & & $\mathrm{AB}$ & & $\mathrm{e}$ \\
\hline Golek RSP 4 & & & AA & & & & & d \\
\hline Golek RSP 5 & & & $\mathrm{AC}$ & $\mathrm{CC}$ & & $\mathrm{AB}$ & & e \\
\hline Golek RSP 6 & & & $\mathrm{AC}$ & & & & & $\mathrm{e}$ \\
\hline Golek RSP 7 & & & & AA & & & & d \\
\hline Golek RSP 8 & & & c & & $\mathbf{A B}$ & $\mathrm{AB}$ & & e \\
\hline Golek RSP 9 & & & & & & $\mathrm{AB}$ & & e \\
\hline Golek RSP 10 & & & & & & $\mathrm{AB}$ & & $\mathrm{e}$ \\
\hline Golck RSP 11 & & & & & & $\mathrm{AB}$ & & e \\
\hline Golek RSP 13 & & & c & $\mathrm{CC}$ & & & & e \\
\hline Golek RSP 18 & & & c & & & & & $\mathrm{e}$ \\
\hline Golek RSP 21 & & & & $\mathrm{CC}$ & & & & d \\
\hline Golek RSP 23 & & & & AA & & & & d \\
\hline Golek RSP 24 & & & c & & & & & e \\
\hline Golek RSP 25 & & & & $\mathrm{CC}$ & & & & d \\
\hline
\end{tabular}

${ }^{2} \mathrm{RSP}=$ Rootstock plant number.

${ }^{y} x^{2}=35.53(P<0.001)$ for comparison of frequencies of off-type seedlings between the five polyembryonic rodtstock cultivars.

${ }^{\mathrm{x}} \mathrm{a}=$ Two-banded phenotype, $\mathrm{b}=$ four-banded phenotype, $\mathrm{c}=$ five-banded phenotype, $\mathrm{d}=$ resulted from self- or cross-pollination $\mathrm{e}=$ resulted from cross-pollination. (Phenotypes not designated were identical to parent type.)

Table 2. Isozyme phenotypes of Turpentine rootstock mother trees.

\begin{tabular}{|c|c|c|c|c|c|c|}
\hline Miami no. & Location & GPI-2 & $\mathrm{IDH}$ & LAP & PGM-1 & TPI \\
\hline 5158 & N2-1-4-6 & $\mathrm{AC}$ & $\mathrm{AC}$ & $\mathrm{AA}$ & $\mathrm{AC}$ & $\mathrm{AB}$ \\
\hline 6878 & WB3-20-12 & $\mathrm{AC}$ & $\mathrm{AC}$ & $\mathbf{A A}$ & $\mathrm{AC}$ & AB \\
\hline 26463 & N2-1-3-2 & $\mathrm{AC}$ & $\mathrm{AC}$ & $\mathbf{A A}$ & $A C$ & $\mathrm{AB}$ \\
\hline \multirow[t]{4}{*}{30602} & N2-1-3-1 & $A C$ & $\mathrm{CC}^{\mathrm{z}}$ & AA & $\mathrm{AC}$ & $A B$ \\
\hline & N2-1-4-3 & $\mathbf{A A}^{\mathbf{z}}$ & $\mathrm{CC}^{\mathrm{z}}$ & $\mathbf{A A}$ & $\mathrm{AA}^{\mathrm{z}}$ & $\mathrm{AB}$ \\
\hline & N2-1-5-8 & $\mathrm{AC}$ & $\mathrm{AC}$ & $\mathrm{AA}$ & $\mathrm{AC}$ & $\overline{A B}$ \\
\hline & N3-1-7-2 & $\mathrm{AC}$ & $\mathrm{AC}$ & AA & $\mathrm{AA}^{\mathrm{z}}$ & $\mathbf{A A}^{2}$ \\
\hline 34171 & N4-1-1-10 & $\mathrm{AC}$ & $\mathrm{AC}$ & $\mathrm{AA}$ & $\mathrm{AC}$ & $\mathrm{AB}$ \\
\hline Israel & & $\mathrm{AC}$ & $A C$ & $\mathbf{A A}$ & $\mathrm{AC}$ & $\mathrm{AB}$ \\
\hline
\end{tabular}

'Off-types.

were used to estimate the frequency of zygotics occurring within the most vigorous seedlings of the five rootstock seedling populations. Immature leaf tissue of each of the 125 seedlings was collected in Dec. 1989. After collection, 400-mg sections were cut from lamella tissue and ground in a chilled mortar in $2 \mathrm{ml}$ of crushing buffer (Degani et al., 1990). The ground tissue and buffer mixture was centrifuged at $30,000 \times g$ for 10 min. Wicks (Whatman 3-mm chromatography paper, $3 \times 6 \mathrm{~mm}$ ) were dipped into the supernatant and stored at $-70 \mathrm{C}$.
Starch gels were prepared by mixing hydrolyzed starch [11\% (w/v); Connaught Laboratories, Ont., Canada] with gel buffer following the procedure of Marty et al. (1984). The starch solution was poured into a plexiglass gel form $(18.5 \times 16.2 \times 0.6 \mathrm{~cm})$, allowed to cool, and placed into a chromatography chamber at $4 \mathrm{C}$. Wicks were placed into the gels no more than $10 \mathrm{~min}$ before use. Electrophoresis was conducted using the buffer systems and procedures of Degani et al. (1990), except for phosphoglucomutase (PGM). Under our conditions, PGM re- solved better in Tris.citric acid buffer, $\mathrm{pH}$ 6.7, than in Poulik buffer. Electrophoresis was continued for the recommended time or, if the system formed a front, until the front had migrated 8 to $10 \mathrm{~cm}$. Gels were usually cut into three slices and stained for three enzymes. The gels were trimmed to remove the portion anodal to the front. Stains were prepared as described by Soltis et al. (1983) for the following enzymes: isocitrate dehydrogenase (EC 1-1.1.42) (IDH), leucine aminopeptidase (EC 3.4.11.1) (LAP), glucose6-phosphate isomerase (EC 5.3.1.9) (GPI), PGM (EC 2.7.5.1), and triosephosphate isomerase (EC 5.3.1.1) (TPI).

Isozyme phenotypes were consistent with previous reports in mango (Degani et al., 1990), with the exception of GPI (Fig. 1). GPI generally has two loci that occur in most diploid plants. One locus is localized in the chloroplast, the other in the cytosol. The enzyme is dimeric, but only polypeptides with the same subcellular localization associate (Gottlieb, 1977; Weeden and Gottlieb, 1979). In mango, two staining regions are apparent. The fast-migrating zone, labelled GPI-1, is monomorphic. The slow-migrating zone, labelled GPI-2, is polymorphic, and six or more phenotypes were observed: AA (one fast-migrating band); $\mathrm{AB}$, the triple-banded phenotype that was not seen by Degani et al. (1990), which may indicate another allele at this locus; $\mathrm{AC}$, the phenotype analogous to Degani et al.'s (1990) AB; and the CC phenotype. In addition to these patterns, several five-banded, four-banded, and two-banded patterns were seen in single seedlings from Golek and Madoe (Fig. 1). These patterns are not easily explained using a single-locus model. GPI may be a three-locus system similar to that found in avocado by Goldring et al. (1985), which would explain these banding patterns. Mango is believed to have an allopolyploid origin (Singh, 1960); therefore, duplicated nuclear loci may occur.

The seedlings from each rootstock were classified as maternal-type (nucellar) or offtype (zygotic) based on the isozyme phenotypes (Table 1). A contingency table was calculated and chi-square values estimated (Snedecor and Cochran, 1967) to determine whether observed differences in off-type frequencies were significant. With $x^{2}=35.53$ ( $4 \mathrm{df}$ and $P<0.001$ ), significant differences existed between cultivars. The range of variation was from zero off-types in 13-1 to 16 of 25 in Golek (Table 1). The percentage of off-types reported for 13-1 in Israel was from $10 \%$ to $15 \%$, but we did not find off-types among the 25 seedlings of 13-1. This result may be attributed to the small sample size, to cross incompatibility with surrounding cultivars, or to the relative vigor of 13-1 nucellar embryos. The percentage of off-types in Sabre was also very low-4\%. The percentages in Turpentine and Madoe were high- $24 \%$ and $36 \%$, respectively.

The number of heterozygous loci differed among the rootstock cultivars. Turpentine and 13-1 are heterozygous at four loci, Madoe is heterozygous at two, and Golek and Sabre heterozygous at one. The probability of de- 
tecting individuals from self-pollination was much greater in 13-1 and Turpentine seedlings because they had more heterozygous loci. No outcrossed or self-pollinated individuals were detected among seedlings of 13-1. Turpentine produced three plants that resulted from cross-pollination and three that could have resulted from self-pollination. All off-types of Madoe resulted from cross-pollination, while among off-types of Golek, 10 were from cross-pollination and six could have resulted from selfing. The single off-type seedling detected in Sabre was from crosspollination (Table 1). The percentage of seedlings resulting from self-pollination may be underestimated in Golek, Madoe, and Sabre because of the low number of heterozygous loci.

Mango is polygamous, and some flowers are unisexual (staminate) while others are bisexual, both types being produced in the same panicle. Self- and cross-incompatibilities are known to exist in mango; however, the mechanism and degree of incompatibility are not understood. Turpentine and 13-1 were found to be self-incompatible in pollination studies (Gazit and Knight, 1989); therefore, it is unlikely that any of the seedlings from Turpentine or 13-1 resulted from self-pollination. The fact that off-type seedlings of Madoe could not have resulted from selfing may indicate that this cultivar is also selfincompatible, but, to our knowledge, information on self- and cross-incompatibilities of Madoe, Golek, and Sabre does not exist.

Turpentine seed that produced the seedlings reported in Table 1 were collected from eight trees. Isozyme phenotypes of the mother trees revealed three trees with patterns dif- ferent than those reported by Degani et al. (1990) (Table 2). Turpentine was carried from our laboratory to Israel in 1980. The distribution record indicates that 200 seeds were collected from M-26463 (local accession number). The isozyme phenotye recorded by Degani et al. (1990) match our phenotypes for that tree. Four of the trees in Miami were planted in 1932 and were given the same local number, M-30602. Their source is unknown and all off-type Turpentine trees are from this introduction. There is no consistent isozyme banding pattern among the three Turpentine trees that differs from the most common phenotype. We conclude from this evidence that the true Turpentine is the most common pattern observed. The identification of this mixture of isozyme phenotypes of mother trees is an example of how this procedure can be used to help certify rootstock mother trees. The off-type seedlings of Turpentine (Table 1) do not have the isozyme phenotypes of any of the three off-type mother stocks and are therefore considered zygotic.

Significant differences were observed between polyembryonic cultivars for the number of zygotic seedlings produced for rootstocks under our conditions. Isozymes are useful in mother tree identification when phenotypes are known, as has been demonstrated here. The zygotic seedlings identified in this study need to be evaluated as rootstocks to see if they affect productivity of the scion cultivar.

\section{Literature Cited}

Degani, C., R. El-Batsri, and S. Gazit. 1990. Enzyme polymorphism in mango. J. Amer. Soc. Hort. Sci. 115:844-847.
Gazit, S. and R.J. Knight. 1989. Asexual embryogenesis in the mango. BARD Project Rpt. I-255-80.

Goldring, A., D. Zamir, and C. Degani. 1985. Duplicated phosphoglucose isomerase genes in avocado. Theor. Appl. Gen. 71:491-494.

Gottlieb, L.D. 1977. Evidence for duplication and divergence of the structural gene for phosphoglucoisomerase in the diploid species of Clarkia. Genetics 86:289-307.

Knight, R.J. 1970. Polyembryonic mangos: Their unrealized potential. Proc. Trop. Reg. Amer. Soc. Hort. Sci. 14:145-155.

Marty, T.L., D.M. O'Malley, and R.P. Gurries. 1984. A manual for starch gel electrophoresis: New microwave edition. School of Natural Resources, College of Agricultural and Life Sciences, Univ. of Wisconsin-Madison. Staff Paper Ser. 20

Moore, G.A. and W.S. Castle. 1988. Morpholog ical and isozymic analysis of open-pollinated citrus rootstock populations. J. Hered. 79(1):5963.

Singh, L.B. 1960. The mango: Botany, cultivation and utilization. Interscience Publ., New Y ork.

Snedecor, G.W. and W.G. Cochran. 1967. Statistical methods. The Iowa State University Press, Ames.

Soltis, D.E., C.H. Haufler, D.C. Darrow, and G.J. Gastony. 1983. Starch gel electrophoresis of ferns: A compilation of grinding buffers, gel and electrode buffers, and staining schedules. Amer. Fern J. 73(1):9-27.

Weeden, N.F. and L.D. Gottlieb. 1979. Distinguishing allozymes and isozymes of phosphoglucoisomerases by electrophoretic comparisons of pollen and somatic tissue. Biochem. Gen. $17: 287-296$ 